\title{
PENGARUH HARGA DAN LOKASI TERHADAP MINAT BELI TANAH KAVLING
}

\author{
Hermansyah \\ Fakultas Ilmu Sosial dan Ilmu Politik Universitas Kapuas Sintang \\ Jl. Y.C. Oevang Oeray Nomor 92 Sintang \\ Email: hermansyah.unkas90@gmail.com
}

\begin{abstract}
ABSTRAK: Penelitian ini bertujuan untuk mengetahui pengaruh harga dan lokasi terhadap minat beli tanah kavling pada CV. Jasa Taruna. . Responden penelitian adalah konsumen yang telah membeli tanah kavling CV. Jasa Taruna. Jumlah responden penelitian ditetapkan dengan menggunakan rumus Solovin sebanyak 65 responden dengan menggunakan teknik pengambilan sampel yaitu Random sampling. Penelitian ini menggunakan analisis data dilakukan dengan dengan bantuan program SPSS. Hasil penelitian menunjukkan Variabel Harga $\left(\mathrm{X}_{1}\right)$ dan Variabel Lokasi $\left(\mathrm{X}_{2}\right)$ secara parsial dan secara simultan berpengaruh secara positif dan significan terhadap Minat Beli (Y) Tanah Kavling pada CV. Jasa Taruna.
\end{abstract}

Kata kunci : Harga, Lokasi, Minat Beli

Pertumbuhan Penduduk yang terus meningkat mendorong tingginya kebutuhan masyarakat akan tempat tinggal yang layak dan terjangkau. Hal ini memberikan peluang yang cukup baik terhadap pelaku binis yang bergerak di bidang real estate untuk mengakomodir kebutuhan masyarakat akan lahan berupa tanah Kavling. Lokasi yang dicari biasanya yang dekat dengan fasilitas umum. Selain itu, lalu memberikan kemudahan akses dan tentunya tidak terlalu masuk sehingga sulit ditemukan. Mencari tempat yang strategis ini penting termasuk untuk bisnis tanah kavling. Tempat yang strategis akan juga menjadi daya tarik tersendiri yang bisa meningkatkan minat pembeli. Tanah kavling yang strategis memiliki beberapa keuntungan yaitu harga jualnya yang lebih tinggi, kemudian mudah terjual dan banyak lagi keuntungan yang lainnya.

CV. Jasa Taruna merupakan usaha property yang dikelola dan dirikan dengan sistem partnership. CV. Jasa Taruna akan memberi solusi yang tepat bagi konsumen untuk memiliki tanah yang aman, lingkungan yang nyaman dan memiliki nilai investasi yang tinggi. CV. Jasa Taruna adalah Perseroan Komanditer yang bergerak pemasaran tanah kavlingan. Dalam memasarkan Tanah Kavling selalu berorientasi pada konsumen, dimana selalu memasarkan tanah kavling dengan lokasi yang strategis dan harga yang terjangkau serta pembayaran dengan sitem angsuran atau kredit.

CV. Jasa Taruna telah berhasil memasarkan kepada 184 orang konsumen dengan lokasi Akcaya 1 sebanyak 57 orang konsumen, lokasi tugu Jam sebanyak 60 orang konsumen dan lokasi Jerora 2 sebanyak 67 orang konsumen. Sementara dari masing-masing lokasi memiliki harga yang berbeda. Tanah Kavling di lokasi
Akcaya 1 dijual dengan harga Rp 18.000.000 perkavling. Tanah Kavling di lokasi Tugu Jam dijual dengan harga Rp Rp 16.000.000 perkavling. Tanah Kavling di lokasi Jerora 2 dijual dengan harga Rp Rp 13.000.000 perkavling. Sebagaimana diketahui bahwa dalam memasarkan tanah kavlingan yang dilakukan oleh CV. Jasa Taruna mendapatkan persaingan yang cukup berat. Banyak dari perusahaan sejenis seperti: CV. Sentra Property; CV. Bumi Senentang Adhyatsa; CV. Pion Langit Jaya; CV. Sugi Graha Indah; CV. Borneo Sejahtera Abadi dan CV. Perdana Property. Perusahaanperusahaan tersebut juga menawarkan tanah kavlingan dengan harga yang bersaing dan lokasi yang strategis.

Pemasaran adalah merupakan kegiatankegiatan dalam suatu perusahaan secara jangka pendek diarahkan untuk memperoleh keuntungan atau laba. Secara jangka panjang kegiatan pemasaran dilakukan perusahaan untuk mempertahaankan kelangsungan hidup perusahaan, memenangkan persaingan diantara perusahan sejenis dan pengembangan atau perluasan usaha. Sejalan dengan pelaksanaan kegiatan Kotler dan Armstrong (2008), memberikan pengertian Pemasaran merupakan proses di mana perusahaan menciptakan nilai bagi pelanggan dan membangun hubungan yang kuat dengan pelanggan dengan tujuan untuk menangkap nilai dari pelanggan sebagai imbalannya.

Definisi yang paling luas yang dapat menerangkan secara jelas arti pentingnya pemasaran dikemukakan oleh Stanton, (dalam Swastha, 2000) Pemasaran adalah suatu sistem keseluruhan dari kegiatan-kegiatan bisnis yang ditujukan untuk merencanakan, menentukan harga, mempromosikan dan mendistribusikan 
barang dan jasa yang memuaskan kebutuhan baik kepada pembeli yang ada maupun pembeli potensial.

Menurut Swastha (2000) terdapat tiga unsur pokok dalam konsep pemasaran adalah: Orientasi pada konsumen, penyusunan kegiatan pemasaran secara integral (integraded marketing) dan kepuasan konsumen (consumer satisfaction). Seluruh kegiatan dalam suatu perusahaan yang menganut konsep pemasaran harus diarahkan untuk memenuhi tujuan tersebut. Penggunaan konsep pemasaran bagi sebuah perusahaan dapat menunjang keberhasilan bisnis yang dilakukan.

Harga memegang peranan penting dalam memasarkan suatu produk. Bila harga terlalu mahal, maka produk bersangkutan bakal tidak terjangkau oleh pasar sasaran tertentu atau bahkan customer value menjadi rendah. Sebaliknya, jika harga terlampau murah, perusahaan sulit mendapatkan laba atau sebagian konsumen mempersepsikan kualitasnya buruk.

Menurut Daryanto (2013) mendefinisikan harga adalah jumlah uang yang ditagihkan untuk suatu produk atau sejumlah nilai yang dipertukarkan konsumen untuk manfaat memiliki atau menggunakan produk. Sedangkan menurut Grewal dan Levy (dalam Tjiptono, 2015) merumuskan definisi harga adalah sebagai berikut: Harga sebagai pengorbanan keseluruhan yang bersedia dilakukan konsumen dalam rangka mendapatkan produk, serta pengorbanan lainnya, baik dalam bentuk non-moneter seperti nilai waktu yang dibutuhkan untuk mendapatkan produk atau jasa maupun moneter (seperti biaya transportasi pajak, biaya pengiriman, dan seterusnya. Menurut Tjiptono (2015) secara garis besar peranan harga dapat dijabarkan sebagai berikut : (1) Harga yang dipilih berpengaruh langsung terhadap tingkat permintaan dan menentukan tingkat aktivitas. Harga yang terlampau mahal atau sebaliknya terlalu murah berpotensi menghambat pengembangan produk. (2) Harga jual secara langsung menentukan profitabilitas operasi. (3) Harga yang ditetapkan oleh perusahaan mempengaruhi persepsi umum terhadap produk atau merek dan berkontribusi pada positioning merek. (4)Harga merupakan alat atau wahana langsung untuk melakukan perbandingan antar produk atau merek yang saling bersaing. (5) Strategi penetapan harga harus selaras dengan komponen bauran pemasaran lainnya. Harga harus dapat menutup biaya pengembangan, promosi, dan distribusi produk. (6) Akselerasi perkembangan teknologi dan semakin singkatnya siklus hidup produk menuntut penetapan harga yang akurat sejak awal. (7) Proliferasi merek dan produk yang seringkali tanpa dibarengi diferensiasi memadai berimplikasi pada pentingnya positioning harga yang tepat. (8) Peraturan pemerintah, etika, dan pertimbanagn sosial (seperti pengendalain harga, penetapan margin laba maksimum, otorisasi kenaikan harga, dan seterusnya) membatasi otonomi dan fleksibilitas perusahaan dalam menetapkan harga. (9) Berkurangnya daya beli di sejumlah kawasan dunia berdampak pada semakin tingginya sensitivitas harga, yang pada gilirannya memperkuat peranan harga sebagai instrumen pendorong penjualan dan pangsa pasar.

Menurut Kotler dan Armstrong (2012) menjelaskan Ada empat ukuran yang mencirikan harga yaitu keterjangkauan harga, kesesuaian harga dengan kualitas produk, kesesuaian harga dengan manfaat, dan harga sesuai dengan kemampuan atau daya saing harga.

Keterjangkaun harga konsumen bisa menjangkau harga yang telah ditetapkan oleh perusahaan. Produk biasanya ada beberapa jenis dalam satu merek harganya juga berbeda dari yang termurah sampai termahal. Dengan harga yang di tetapkan para konsumen banyak yang membeli produk.

Kesesuaian harga dengan kualitas produk. Harga sering dijadikan sebagai indikator kualitas bagi konsumen. Orang sering memilih harga yang lebih tinggi diantara dua barang karena mereka melihat adanya perbedaan kualitas. Apabila harga lebih tinggi orang cenderung beranggapan bahwa kualitasnya juga lebih baik.

Kesesuaian harga dengan manfaat Konsumen memutuskan membeli suatu produk jika manfaat yang dirasakan lebih besar atau sama dengan yang telah dikeluarkan untuk mendapatkannya. Jika konsumen merasakan manfaat produk lebih kecil dari uang yang dikeluarkan maka konsumen akan beranggapan bahwa produk tersebut mahal dan konsumen akan berpikir dua kali untuk melakukan pembelian ulang.

Harga sesuai kemampuan atau daya saing harga Konsumen sering membandingkan harga suatu produk dengan produk lainnya. Dalam hal ini mahal murahnya suatu produk sangat dipertimbangkan oleh konsumen pada saat akan membeli produk tersebut.

Menurut Stanton (2012) terdapat empat indikator yang mencirikan harga, yaitu: (1). Keterjangkauan harga; (2). Kesesuaian harga dengan kualitas produk; (3). Daya saing harga; (4). Kesesuaian harga dengan manfaat. Harga akan menjadi pertimbangan yang cukup penting bagi konsumen dalam memutuskan pembelian. Konsumen akan membandingkan harga dari produk pilihan mereka dan kemudian mengevaluasi kesesuaian harga tersebut dengan nilai produk atau jasa serta jumlah uang yang harus dikeluarkan. 
Ratnasari dan Aksa (2011) menyatakan bahwa: lokasi merupakan keputusan yang dibuat perusahaan berkaitan dengan dimana operasi dan stafnya akan ditempatkan. Lokasi berpengaruh terhadap dimensi-dimensi strategik, seperti fleksibilitas, competitive positioning, manajemen permintaan, dan focus strategic

Fleksibilitas sebuah lokasi merupakan suatu ukuran sejauh mana sebuah barang atau jasa mampu bereaksi terhadap situasi perekonomian yang berubah. Keputusan pemilihan lokasi berkaitan dengan komitmen jangka panjang terhadap aspekaspek yang sifatnya capital intensif, karena itu penyedia barang dan jasa harus mempertimbangkan, menyeleksi dan memilih lokasi yang responsif terhadap kemungkinan perubahan ekonomi, demografis, budaya, persaingan dan peraturan di masa mendatang.

Menurut Tjiptono dan Chandra (2011) Competitive Positioning adalah metode-metode yang digunakan agar perusahaan dapat mengembangkan posisi relatifnya dibandingkan dengan para pesaing. Jika perusahaan berhasil memperoleh dan mempertahankan lokasi yang strategis, maka itu dapat menjadi rintangan yang efektif bagi para pesaing untuk mendapatkan akses ke pasar.

Perusahaan juga memperhitungkan pemilihan lokasi yang sesuai dengan starategi perusahaan dan memilih lokasi yang responsif apabila terjadi perubahan ekonomi, demografi, budaya saing atau peraturan yang berlaku dimasa yang akan datang, sehingga perusahaan tidak mengalami kesulitan yang tidak diinginkan dikemudian hari. Pemilihan lokasi perusahaan juga memperhitungkan posisi pelanggan.

Menurut Kotler dan Amstrong (2008) menyatakan bahwa lokasi atau tempat merupakan kegiatan perusahaan yang membuat produk tersedia bagi pelanggan sasaran. Pemilihan lokasi sangat penting adalah pelanggan mendatangi perusahaan. Perusahaan harus memilih dengan cermat agar memudahkan pelanggan. Menurut Tjiptono dan Chandra (2005), pemilihan lokasi fisik memerlukan pertimbangan cermat terhadap factorfaktor: (1) Akses; (2) Visibilitas; (3) Lalu lintas; (4) Tempat parkir yang luas dan aman; (5) Ekspansi; (6) Lingkungan; (7) Kompetisi, yaitu lokasi pesaing dan (8) Peraturan Pemerintah yang berisi ketentuan untuk mengatur lokasi dari sebuah usaha-usaha tertentu.

Berdasarkan beberapa pendapat ahli tersebut dalam pemilihan lokasi, perusahaan harus menentukan sasaran pelanggan yang ingin dijaring, dengan begitu perusahaan bisa mendekati pelanggan. Selain itu, pemilihan lokasi juga memerhatikan akses dan visibilitas agar memudahkan pelanggan. Sejalan dengan semakin menjamurnya bisnis atau usaha yang menawarkan barang dan jasa yang sejenis, perbedaan yang sangat tipis sekalipun pada lokasi dapat berdampak kuat pada pangsa pasar dan kemampulabaan sebuah usaha. Perusahaan tidak hanya memikirkan efek jangka pendeknya saja, tetapi dalam memilih sebuah lokasi untuk menjalankan usahanya juga harus memikirkan jangka panjang. Selain itu, perusahaan juga harus mengikuti peraturanperaturan yang dibuat oleh pemerintah guna memperlancar usahanya tersebut.

Perilaku konsumen (consumer behavior) dapat didefinisikan sebagai kegiatan-kegiatan individu yang secara langsung terlibat dalam mendapatkan dan mempergunakan barang dan jasa, termasuk di dalamnya proses pengambilan keputusan pada persiapan dan penentuan kegiatan-kegiatan tersebut. Menurut Anaroga (2000). Perilaku konsumen merupakan perilaku konsumen yang ditunjukkan melalui pencarian, pembelian, penggunaan, pengevaluasian, dan penentuan produk atau jasa yang diharapkan dapat memuaskan kebutuhan konsumen Sementara Sumarwan (2003) menyatakan bahwa: Perilaku konsumen adalah semua kegiatan, tindakan, serta proses psikologis yang mendorong tindakan tersebut pada saat sebelum membeli, ketika membeli, menggunakan, menghabiskan produk dan jasa setelah melakukan hal-hal di atas atau kegiatan mengavaluasi.

Perilaku konsumen dapat diartikan sebagai atau kegiatan-kegiatan individu, yang secara langsung terlibat dalam mendapatkan serta menggunakan barang-barang dan jasa-jasa termaasuk di dalamnya proses pengambilan keputusan pada persiapan dan penentuan kegiatan tersebut. Pengertian tersebut mengandung unsur yaitu proses pengambilan keputusan sebagai kegiatan yang tidak nampak pada dasarnya termasuk dalam perilaku, karena kegiatan yang tampak adalah atau hasil dari pengambilan keputusan.jadi perilaku konsumen meliputi apa yang dibeli, akan tetapi juga di mana, berapa banyak atau sering dan dalam kondisi bagaimana konsumen membeli suatu barang.

Minat (Interest) digambarkan sebagai situasi dimana konsumen belum melakukan suatu tindakan, yang dapat dijadikan dasar untuk memprediksi perilaku atau tindakan tersebut. Minat beli merupakan pernyataan mental konsumen yang merefleksikan rencana pembelian suatu produk dengan merek terntentu pengetahuan tentang niat beli konsumen terhadap produk perlu diketahui oleh para pemasar untuk mendeskripsikan perilaku konsumen pada masa yang akan datang. Minat beliterbentuk dari sikap konsumen terhadap suatu produk hal tersebut berasal dari keyakinan konsumen terhadap 
kualitas produk. Semakin rendah keyakinan konsumen terhadap suatu produk akan menyebabkan menurunkan minat beli konsumen. Minat beli konsumen pada dasarnya merupakan faktor pendorong dalam pengambilaan keputusan pembelian terhadap suatu produk.

Menurut Kotler (2007) mengatakan Minat merupakan perilaku yang muncul sebagai respon terhadap suatu objek yang menunjukkan keinginan pelanggan untuk melakukan pembelian. Sedangkan Yamit (2001) memberikan pengertian Minat beli konsumen merupakan evaluasi purna beli atau hasil evaluasi setelah membandingkan apa yang dirasak an dengan harapannya. Sementara menurut Durianto, dkk (2003) Minat beli merupakan sesuatu yang berhubungan dengan rencana konsumen untuk membeli produk tertentu, serta berapa banyak unit produk yang dibutuhkan pada periode tertentu.

Thamrin (2003) berpendapat bahwa Minat beli konsumen merupakan bagian dari komponen perilaku konsumen dalam sikap mengkonsumsi, kecenderungan responden untuk bertindak sebelum keputusan membeli benar-benar dilaksanakan. Jadi dapat disimpulkan minat belikonsumen adalah niatan yang timbul dari dalam diri seseorang untuk melakukan pembelian suatu produk atau jasa dengan pertimbangan sebelum proses pembelian berlangsung.

Menurut Ferdinand (2002), minat beli dapat diidentifikasi melalui indikator-indikator sebagai berikut: (1). Minat transaksional; Yaitu kecenderungan seseorang untuk membeli produk. Hal ini bermaksud yakni konsumen telah memiliki minat untuk melakukan pembelian suatu produk tertentu yang ia inginkan. (2). Minat referensial; Yaitu kecenderungan seseorang untuk mereferensikan produk kepada orang lain. Hal ini bermaksud yakni seorang konsumen yang telah memiliki minat untuk membeli akan menyarankan orang terdekatnya untuk juga melakukan pembelian produk yang sama. (3). Minat preferensial; Yaitu minat yang menggambarkan perilaku seseorang yang memiliki preferensi utama pada produk tersebut. Preferensi ini hanya dapat diganti jika terjadi sesuatu dengan produk preferensinya. (4). Minat eksploratif; Minat ini menggambarkan perilaku seseorang yang selalu mencari informasi mengenai produk yang diminatinya dan mencari informasi untuk mendukung sifat-sifat positif dari produk tersebut.

Berdasarkan uaraian di atas dapat dikatakan bahwa untuk mengukur minat belikonsumen dapat dilihat dari beberapa aspek seperti: kecenderungan seseorang untuk membeli produk; kecenderungan seseorang untuk mereferensikan produk kepada orang lain; seseorang yang memiliki preferensi utama pada produk tersebut; dan seseorang yang selalu mencari informasi mengenai produk yang diminatinya.

\section{METODE PENELITIAN}

Penelitian ini dilakukan di CV. Jasa Taruna beralamat di Jalan. J.C. Oevang Oeray Sintang. Pada penelitian ini menggunakan rancangan penelitian korelatif dengan pendekatan secara kuantitatif. Penelitian korelatif digunakan untuk mencari hubungan atau pengaruh variabel bebas Harga dan Lokasi terhadap variabel bebas yaitu Minat Beli Konsumen. Sementara pendekatan scara kuantitatif digunakan perhitungan dengan alat uji berupa statistik. Melalui pendekatan scara kuantitatif ini peneliti akan melakukan pengujian kebenaran atau ketidakbenaran hipotesis. Populasi dalam penelitian adalah konsumen yang membeli tanah kavling pada CV. Jasa Taruna berjumlah 184 orang konsumen. Pengambilan sampel dengan Slovin (Umar, 2005) sebagai berikut:

\section{$\mathrm{N}$}

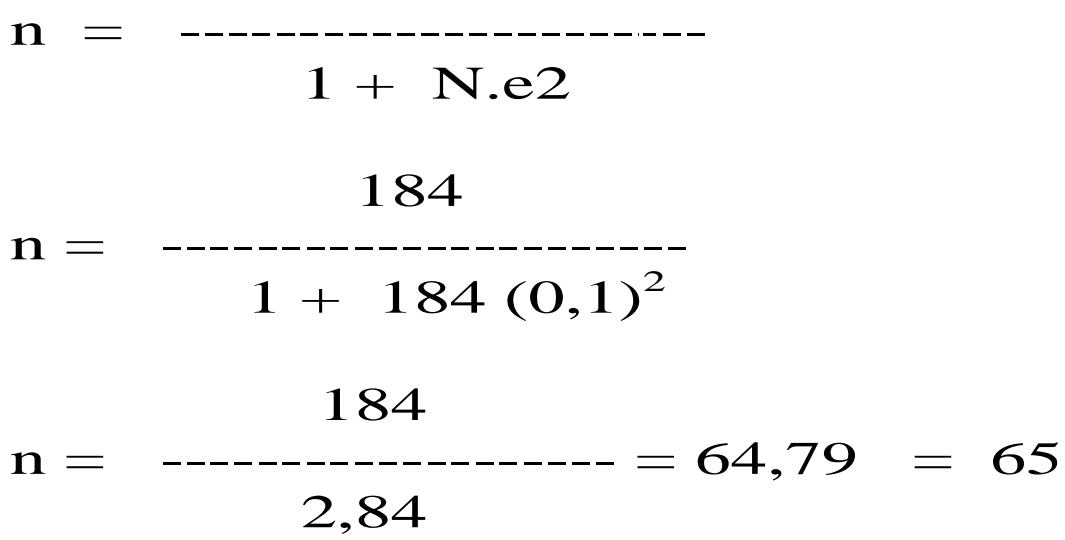


206. Fokus, Volume 18, Nomor 2, September 2020, hlm. 202 - 209

\section{HASIL PENELITIAN DAN PEMBAHASAN}

Hasil Uji Validitas

Harga $\left(\mathbf{X}_{1}\right)$

\begin{tabular}{|c|c|c|c|}
\hline Kuisioner & Pearson Correlation & Sig. (2-tailed) & Keterangan \\
\hline $\mathrm{X} 1.1$ & 0,882 & 0 & Valid \\
\hline $\mathrm{X} 1.2$ & 0,754 & 0 & Valid \\
\hline $\mathrm{X} 1.3$ & 0,842 & 0 & Valid \\
\hline $\mathrm{X} 1.4$ & 0,875 & 0 & Valid \\
\hline $\mathrm{X} 1.5$ & 0,736 & 0 & Valid \\
\hline & & & \\
\hline
\end{tabular}

Lokasi $\left(\mathbf{X}_{2}\right)$

\begin{tabular}{|c|c|c|c|}
\hline Kuisioner & Pearson Correlation & Sig. (2-tailed) & Keterangan \\
\hline $\mathrm{X} 2.1$ & 0,848 & 0 & Valid \\
\hline $\mathrm{X} 2.2$ & 0,783 & 0 & Valid \\
\hline $\mathrm{X} 2.3$ & 0,832 & 0 & Valid \\
\hline $\mathrm{X} 2.4$ & 0,830 & 0 & Valid \\
\hline $\mathrm{X} 2.5$ & 0,738 & 0 & Valid \\
\hline $\mathrm{X} 2.6$ & 0,762 & 0 & Valid \\
\hline $\mathrm{X} 2.7$ & 0,754 & 0 & Valid \\
\hline
\end{tabular}

Minat Beli (Y)

\begin{tabular}{|c|c|c|c|}
\hline Kuisioner & Pearson Correlation & Sig. (2-tailed) & Keterangan \\
\hline Y.1 & 0,802 & 0 & Valid \\
\hline Y.2 & 0,817 & 0 & Valid \\
\hline Y.3 & 0,835 & 0 & Valid \\
\hline Y.4 & 0,834 & 0 & Valid \\
\hline
\end{tabular}

Sumber: Jawaban responden diolah dengan SPSS

Dari tabel di atas dapat dilihat perbandingan apakah seluruh pertanyaaan yang terdapat pada Variabel bebas/independent dan Variabel terikat/dependen jika Sig. (2-tailed) $<0,05$ maka pertanyaan dinyatakan Valid dan jika Sig. (2-tailed) > 0,05 maka pertanyaan dinyatakan tidak Valid. Semua item pertanyaan di dalam kuesioner dinyatakan valid dan layak untuk digunakan di dalam penelitian ini.

Uji Reliabilitas variabel independent Harga $\left(X_{1}\right)$, Lokasi $\left(X_{2}\right.$ serta Uji Reliabilitas variabel terikat/dependent Minat Beli (Y) dilakukan dengan menggunakan bantuan perangkat lunak SPSS, melalui masukan responden sebanyak 65 orang sebagai uji coba, dengan taraf signifikansi $=5 \%$

Hasil Uji Reliabilitas

\begin{tabular}{|c|l|c|c|c|}
\hline No & \multicolumn{1}{|c|}{ Variabel } & $\begin{array}{c}\text { Cronbach's } \\
\text { Alpha }\end{array}$ & $\begin{array}{c}\text { Cronbach's Alpha } \\
\text { Standart }\end{array}$ & Keterangan \\
\hline 1 & Harga $\left(\mathrm{X}_{1}\right)$ & 0,877 & 0,60 & Reliable \\
\hline 2 & Lokasi $\left(\mathrm{X}_{2}\right)$ & 0,898 & 0,60 & Reliable \\
\hline 3 & Minat Beli $(\mathrm{Y})$ & 0,836 & 0,60 & Reliable \\
\hline
\end{tabular}

Sumber: Jawaban responden diolah dengan SPSS 
Hermansyah, Pengaruh Harga dan Lokasi Terhadap Minat Beli Tanah Kavling 207

Instrumen pertanyaan dapat dikatakan andal (reliable) bila memiliki koefisien keandalan reliabilitas sebesar 0,6 atau lebih. Hasil pada tabel di atas menunjukan hasil Cronbach's Alpha > Analisis Regresi Linier Berganda
Cronbach's Alpha Standart dengan demikian semua pertanyaan dapat dikatakan andal (reliable) dalam penelitian ini.

\section{Coefficients $^{\mathrm{a}}$}

\begin{tabular}{|c|c|c|c|c|c|}
\hline \multirow[b]{2}{*}{ Model } & \multicolumn{2}{|c|}{ Unstandardized Coefficients } & \multirow{2}{*}{$\begin{array}{c}\begin{array}{c}\text { Standardized } \\
\text { Coefficients }\end{array} \\
\text { Beta }\end{array}$} & \multirow[b]{2}{*}{$\mathrm{T}$} & \multirow[b]{2}{*}{ Sig. } \\
\hline & $\mathrm{B}$ & Std. Error & & & \\
\hline $1 \quad$ (Constant) & .415 & .421 & & .987 & .327 \\
\hline Harga $\left(\mathrm{X}_{1}\right)$ & .301 & .116 & .380 & 2.606 & .011 \\
\hline Lokasi $\left(\mathrm{X}_{2}\right)$ & .344 & .083 & .602 & 4.124 & .000 \\
\hline
\end{tabular}

a. Dependent Variable: Minat Beli (Y)

Sumber: Jawaban responden diolah dengan SPSS berikut:

Berdasarkan hasil pengolahan data dengan menggunakan program SPSS diperoleh hasil sebagai

1. Regresi Linear Berganda $\mathrm{Y}=0,415+$ $0,301 \mathrm{X}_{1}+0,344 \mathrm{X}_{2}$

2. Nilai $a_{0}$ Nilai intercept $=0,415$ Jika variable Harga dan Variabel Lokasi, sebesar 0, maka variabel Minat beli (Y) Tanah Kavling pada CV. Jasa Taruna sebesar 0,415

3. Nilai $\mathrm{a}_{1}=0,301$ Variabel Harga berpengaruh positif terhadap Minat beli. Jika Variabel Lokasi dianggap tetap, maka setiap penambahan satu satuan Variabel Harga $\left(\mathrm{X}_{1}\right)$ akan meningkatkan Minat Beli sebesar 0,301.

4. Nilai $\mathrm{a}_{2}=0,344$ Variabel Lokasi berpengaruh positif terhadap Minat beli. Jika Variabel Harga dianggap tetap, maka setiap penambahan satu satuan Variabel Lokasi $\left(\mathrm{X}_{2}\right)$ akan meningkatkan variabel Minat beli (Y) Tanah Kavling pada CV. Jasa Taruna sebesar 0,344 .

\section{Uji Korelasi}

Uji korelasi untuk mengukur kekuatan hubungan antara variabel independen dengan variabel dependen. Dari uji korelasi yang telah dilakukan diperoleh hasil sebagai berikut:

\section{Hasil Uii Korelasi}

\section{Correlations}

\begin{tabular}{|c|c|c|c|c|c|}
\hline & & & Harga (X1) & $\begin{array}{l}\text { Lokasi } \\
\text { (X2) }\end{array}$ & $\begin{array}{l}\text { Minat Beli } \\
\text { (Y) }\end{array}$ \\
\hline \multirow[t]{9}{*}{$\begin{array}{l}\text { Spearman's } \\
\text { rho }\end{array}$} & \multirow[t]{3}{*}{ Harga $\left(X_{1}\right)$} & $\begin{array}{l}\text { Correlation } \\
\text { Coefficient }\end{array}$ & 1.000 & $.968^{* *}$ & $.972^{* *}$ \\
\hline & & Sig. (2-tailed) & & .000 & .000 \\
\hline & & $\mathrm{N}$ & 65 & 65 & 65 \\
\hline & \multirow[t]{3}{*}{ Lokasi $\left(\mathrm{X}_{2}\right)$} & $\begin{array}{l}\text { Correlation } \\
\text { Coefficient }\end{array}$ & $.968^{* * *}$ & 1.000 & $.966^{* *}$ \\
\hline & & Sig. (2-tailed) & .000 & & .000 \\
\hline & & $\mathrm{N}$ & 65 & 65 & 65 \\
\hline & \multirow[t]{3}{*}{ Minat Beli (Y) } & $\begin{array}{l}\text { Correlation } \\
\text { Coefficient }\end{array}$ & $.972^{* * *}$ & $.966^{* * *}$ & 1.000 \\
\hline & & Sig. (2-tailed) & .000 & .000 & \\
\hline & & $\mathrm{N}$ & 65 & 65 & 65 \\
\hline
\end{tabular}

**. Correlation is significant at the 0.01 level (2-tailed).

Sumber: Jawaban responden diolah dengan SPSS 
208. Fokus, Volume 18, Nomor 2, September 2020, hlm. 202 - 209

Berdasar data pada tabel di atas maka dapat diketahui:

1. Koefisien korelasi Harga $\left(\mathrm{X}_{1}\right)$ sebesar 0,972 berada pada rentang nilai 0,8 sampai dengan 1, berarti Variabel Harga $\left(\mathrm{X}_{1}\right)$ memiliki hubungan yang sangat kuat dengan Variabel Minat beli (Y) Tanah Kavling pada CV. Jasa Taruna.

2. Koefisien korelasi Lokasi sebesar 0,966 berada pada rentang nilai 0,8 sampai dengan 1, berarti Variabel Lokasi $\left(\mathrm{X}_{2}\right)$ memiliki hubungan yang sangat kuat dengan Variabel Minat beli (Y) Tanah Kavling pada CV. Jasa Taruna.
Dengan demikian dapat disimpulkan bahwa Variabel Harga $\left(X_{1}\right)$ dan Variabel Lokasi $\left(X_{2}\right)$ sama-sama memiliki hubungan sangan kuat dengan Variabel Minat beli (Y) Tanah Kavling pada CV. Jasa Taruna.

\section{Uji t}

Uji t digunakan untuk mengetahui pengaruh secara parsial variabel independen (Variabel Harga dan Variabel Lokasi) terhadap variabel dependen (Minat Beli). Signifikan pengaruh dapat diestimasi dengan membandingkan nilai Sig dengan dengan tingkat keyakinan $95 \%$ atau $\alpha=0,05$. Hasil perhitungan uji t dapat dilihat pada Tabel berikut ini.

\section{Nilai t Hitung}

\begin{tabular}{|c|c|c|c|}
\hline \multicolumn{4}{|c|}{ Coefficients $^{\mathrm{a}}$} \\
\hline \multicolumn{2}{|c|}{ Model } & $\mathrm{t}$ & Sig. \\
\hline \multirow[t]{3}{*}{1} & (Constant) & ,987 &, 327 \\
\hline & Harga $\left(X_{1}\right)$ & 2,606 & ,011 \\
\hline & Lokasi $\left(\mathrm{X}_{2}\right)$ & 4,124 & ,000 \\
\hline
\end{tabular}

a. Dependent Variable: Minat Beli (Y)

Sumber: Jawaban responden diolah dengan SPSS

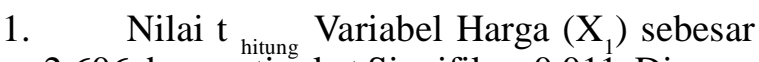
2,606 dengan tingkat Signifikan 0,011. Dimana $0,011<0,05$ maka keputusan uji hipotesis dengan menerima $\mathrm{H}_{\mathrm{a}}$ dan menolak $\mathrm{H}_{0}$. Berarti Variabel Harga berpengaruh positif dan signifikan terhadap Variabel Minat beli (Y) Tanah Kavling pada CV. Jasa Taruna.

2. Nilai $t_{\text {hitung }}$ Variabel Lokasi $\left(\mathrm{X}_{2}\right)$ sebesar 4,124 dengan tingkat Signifikan 0,000. Dimana $0,000<0,05$ maka keputusan uji hipotesis dengan menerima $\mathrm{H}_{\mathrm{a}}$ dan menolak $\mathrm{H}_{0}$. Berarti Variabel Lokasi berpengaruh positif dan signifikan terhadap Variabel Minat beli (Y) Tanah Kavling pada CV. Jasa Taruna.

\section{Uji F}

Uji F digunakan untuk mengetahui pengaruh secara Simultan variabel independen (Variabel Harga dan Variabel Lokasi) terhadap variabel dependen (Minat Beli). Signifikan pengaruh dapat diestimasi dengan membandingkan nilai Sig dengan dengan tingkat keyakinan $95 \%$ atau $\alpha=0,05$. Hasil perhitungan uji $\mathrm{F}$ dapat dilihat pada tabel berikut ini:

ANOVA $^{b}$

\begin{tabular}{|c|c|c|c|c|c|c|}
\hline \multicolumn{2}{|c|}{ Model } & Sum of Squares & df & Mean Square & $\mathrm{F}$ & Sig. \\
\hline \multirow[t]{3}{*}{1} & Regression & 224.016 & 2 & 112.008 & 699.857 & $.000^{\mathrm{a}}$ \\
\hline & Residual & 9.923 & 62 & .160 & & \\
\hline & Total & 233.938 & 64 & & & \\
\hline
\end{tabular}

a. Predictors: (Constant), Lokasi (X2), Harga (X1)

b. Dependent Variable: Minat Beli (Y)

Sumber: Jawaban responden diolah dengan SPSS

Berdasarkan tabel Anova di atas, dapat diketahui nilai $\mathrm{F}$ hitung sebesar 699,857 dan nilai Sig. sebesar 0,000. Nilai nilai Sig. sebesar 0,000 ini akan dibandingkan dengan nilai $\alpha=0,05$. Dimana Nilai Sig. 0,000 lebih kecil dari Nilai $\quad \alpha=0,05$, terdapat pengaruh simultan yang signifikan dari variabel Harga dan Variabel Lokasi terhadap Variabel Minat beli (Y) Tanah Kavling pada CV. Jasa Taruna. sehingga $\mathrm{H}_{\mathrm{a}}$ diterima dan $\mathrm{H}_{0}$ ditolak , artinya 
Hermansyah, Pengaruh Harga dan Lokasi Terhadap Minat Beli Tanah Kavling 209

\section{Koefesien Determinasi $\left(\mathbf{R}^{2}\right)$}

Analisis koefesien determinasi $\left(\mathrm{R}^{2}\right)$ digunakan untuk mengetahui berapa besar kontribusi variabel independen terhadap variasi naik turunnya variabel dependen. Nilai $R^{2}$ ini berkisar antara $0<R^{2}<1$.

Model Summary

\begin{tabular}{|c|c|c|c|c|}
\hline Model & $\mathbf{R}$ & R Square & Adjusted R Square & $\begin{array}{l}\text { Std. Error of the } \\
\text { Estimate }\end{array}$ \\
\hline 1 & $.979^{\mathrm{a}}$ & .958 & .956 & .40005 \\
\hline
\end{tabular}

a. Predictors: (Constant), Lokasi (X2), Harga (X1)

Sumber: Jawaban responden diolah dengan SPSS

Nilai $R=0,979$. Ini menunjukan terdapat hubungan yang sangat kuat antara Variabel Harga $\left(\mathrm{X}_{1}\right)$, Variabel Lokasi $\left(\mathrm{X}_{2}\right)$, dengan Variabel Minat Beli (Y) Tanah Kavling pada CV. Jasa Taruna. koefisien determinasi atau $R$ square sebesar 0,958 atau $95,8 \%$. Hal ini menunjukkan bahwa Variabel Harga $\left(\mathrm{X}_{1}\right)$, Variabel Lokasi $\left(\mathrm{X}_{2}\right)$ secara simultan memberikan pengaruh terhadap Minat $\operatorname{Beli}(\mathrm{Y})$ Tanah Kavling pada CV.sebesar 95,8\%. sedangkan sisanya sebesar $100 \%$ - 95,8\% $=4,2 \%$ dipengaruhi oleh faktor lain di luar persamaan model regresi.

\section{KESIMPULAN DAN SARAN}

Berdasarkan hasil penelitian bahwa hubungan antara Harga $\left(\mathrm{X}_{1}\right)$, Lokasi $\left(\mathrm{X}_{2}\right.$ dengan variabel Minat Beli (Y) Tanah Kavling pada CV. Jasa Taruna digambarkan melalui persamaan Regresi Linear Berganda $Y=0,415+0,301 X_{1}+$ $0,344 X_{2}$. Variabel Harga $\left(X_{1}\right)$ dan Variabel Lokasi $\left(\mathrm{X}_{2}\right)$ secara parsial dan secara simultan berpengaruh secara positif dan significan terhadap Minat Beli (Y) Tanah Kavling pada CV. Jasa Taruna. Variabel Harga $\left(\mathrm{X}_{1}\right)$ dan Variabel Lokasi $\left(X_{2}\right)$ memiliki hubungan yang sangat erat dengan Minat Beli (Y). Variabel Harga $\left(\mathrm{X}_{1}\right)$, Variabel Lokasi $\left(\mathrm{X}_{2}\right)$ secara simultan memberikan pengaruh terhadap Minat Beli (Y) Tanah Kavling pada CV Jasa Taruna sebesar 95,8\%. sedangkan sisanya sebesar $100 \%-95,8 \%=4,2 \%$ dipengaruhi oleh faktor lain di luar persamaan model regresi. Mengingat bawa Variabel Harga $\left(X_{1}\right)$ dan Variabel Lokasi $\left(\mathrm{X}_{2}\right)$ memiliki hubungan positif dan pengaruh yang sangat signifikan terhadap Minat Beli (Y) sudah selayaknya CV Jasa Taruna mampu bersaing dengan perusahaan sejenis lainnya dalam menawarkan tanah kavling dengan harga rendah dan memilih tempat yang lokasi yang strategis.

\section{DAFTAR PUSTAKA}

Anoraga. Pandji. 2000. Manajemen Bisnis. Jakarta: PT. Rineka Cipta

Daryanto. 2013. Sari Kuliah Manajemen Pemasaran. Bandung: PT. Sarana Tutorial Nurani Sejahtera
Durianto. dkk. 2003. Invasi Pasar dengan Iklan yang Efektif: Strategi. Program. dan Teknik Pengukuran. Jakarta: Gramedia Pustaka Utama

Ferdinand, Augusty. 2002. Pengembangan Minat Beli Merek Ekstensi. Semarang: Badan Penerbit Universitas Diponegoro.

Kotler, Philip dan Amstrong. 2008. Prinsip-prinsip Pemasaran Edisi 12 Jilid 1. Jakarta: Erlangga.

Ratnasari, Ririn Tri dan Aksa, Mastuti H. 2011. Teori dan Kasus Manajemen Pemasaran Jasa. Jakarta: Galia Indonesia.

Stanton, William J. 2012. Prinsip pemasaran. alih bahasa: Yohanes Lamarto. Jakarta: Penerbit Erlangga

Swastha, Basu. 2000. Pengantar Bisnis Modern. Pengantar Ekonomi Perusahaan Modern. Jakarta : Liberty.

Thamrin, Abdullah. 2003. Manajemen Pemasaran. Jakarta: PT. Rajawali Pers.

Tjiptono dan Chandra. 2005. Manajemen Kualitas Jasa. Yogyakarta: ANDI.

Tjiptono, Fandy. 2011. Strategi Pemasaran. Yogyakarta: Andi

Tjiptono, 2015 Strategi Pemasaran. Yogyakarta: Andi Offset

Yamit, Zulian. 2001. Manajemen Kualitas Produk dan Jasa.Yogyakarta: Ekonosia. 